\title{
GENITAL IMPACTS
}

\author{
Luiz Felipe G. Soares \\ Universidade Federal de Santa Catarina
}

\section{Abstract}

I propose to analyze three images of genitalia from three different films that do not have sex as their central subject: (1) Lígia's (Leona Cavalli's) vulva in Claudio Assis's Amarelo Manga (Brazil, 2002), (2) Stoffer's (Jens Albinus's) erect penis in Lars von Trier's The Idiots(Denmark, 1998), and (3) transsexual Dil's (Jaye Davidson's) penis in Neil Jordan's The Crying Game (USA, 1992). All three images are explicit and surprising enough to provoke impact, both in diegetic and extra-diagetic spaces. I intend to compare the three images and investigate the nature of their impacts, not directly in terms of morality, but in their relation with two theoretical assumptions: (1) the intense way in which, according to Linda Nicholson (1999), so many cultures insist in interpreting bodies and genitalia as still capable of defining gender characters, and (2) the notion of image, not as representation, but as image itself, as "what it is", or as "the place of every transformation in the universe", as suggested first by Bergson (2005), and then by Deleuze (1983-5), Rancière (2001) and Agamben (1995). The Deleuzean retard may indicate the way in which genitalia, as image, turn into enigma, in the very passage from nature to culture. The three shots give back to those clear images of genitalia the property they have always had: their character of central pieces in the game of such 
passage. The contrast between such simple and clear images and all those complex games corresponds to the nature of the impact I want to investigate.

Keywords: film; genitalia; narrative.

What is it like to see a penis or a vagina, suddenly, overtly, on a screen? I do not mean on a porn movie, in which they are exactly what one expects. I refer to films (including mainstream) that are produced and sold according to a sort of contract with spectators in which genitalia are tacitly excluded - a contract which, thus, protects the spectator and his/her children from facing those images, considered by many as moral violence.

Perhaps Courbet's "L'Origine du monde" ${ }^{\prime 1}$ may be seen as a major example of rupture in this kind of contract. Probably most people did not expect to get into an exhibition, around 1866, and see a vagina so realistically painted on a canvas. Yet, the irony of the title insistently reminds them that, certainly, everyone had very intimate contact with the object represented, at least once in his/her life. Although many still have such contact in their everyday life, out of the realm of "art", and precisely because of it, provocations such as Courbet's may produce violent impacts up to these days, perhaps because it refers thought directly, violently, to myths of origin, to the absence of meaning for life itself. The same seems to happen today in some films.

Hard core productions, as Linda Williams points out, drawing on Foucault's Volonté de savoir, have been "the most recent magic" that makes sex itself speak (1999, p. 2). These films and videos are "explicit" not only for showing "speaking sex" itself, but also because they explicitly promise to arouse spectators. Besides Williams, a good amount of authors has recently written on them-such as Walter Kendrick, Laura Kipnis, Drucilla Cornell, and Laurence O'Toole.

Outside the world of hard core, Alain Badiou builds a curious relationship between cinema and sex. When analyzing Antonioni's Identificazione di una donna, Badiou suggests that only cinema is able to "figurar sensiblemente, corporalmente, no-como se cree demasiado 
a menudo-la distribución de los roles sexuados, o las imágenes de esa distribución, sino-y es infinitamente más delicado y más original—el proceso de identificación de lo que ser sexuado significa para un sujeto" (p. 88). For Badiou, cinema undertakes this process of identification as no other kind of cultural production. Sexual scenes "son simultáneamente la obsession y la cruz de este arte de lo visible" (p. 90). Indeed,

El cine es el único arte que puede pretender capturar, fijar y transmitir el acto sexual. Existen novelas pornográficas. Pero el imaginario les basta sobradamente. El poder que tienen las palavras de nombrar lo inexistente puede pornografizar todos los párrafos que se quiera. No hay ninguna necesidad de sexos reales. El cine, por su lado, da testimonio, y cada vez más, de lo real de los órganos, de las posturas, de los gritos y de los sudores. Agencia su visibilidade repetitiva. $Y$ desde hace mucho tiempo, bajo las más duras censuras, el cine hizo saber que podía capturar y transmitir el acto sexual, que sólo él podía hacerlo verdaderamente, y que le bastaba mostrarlo que se llama mostrar - un tobillo, un escote, una media negra o un símbolo para que todos temblaran voluptuosamente frente a la idea de que todo es visible y de que no existe, para el cine, ninguna intimidad que no pueda forzarse y exponerse. Desde este punto de vista, como se he destacado tantas vezes, lo que es pornográfico es el cine en su esencia, o más bien en su posibilidad esencial (p. 90-1).

And then, Badiou asks: “ ¿toda exposición de lo sexual remite a la inhumanidad objetiva de lo que no comporta ningún pensamiento?" (p. 91). Such question acquires special relevance when one remembers Klossowski's famous reading of Sade. In Sade's writing, reiteration (of sexual act) would be the magical solution for saying what is not communicable, and this would be Sade's specificity, his difference from pornography. The glorious instant of sodomy, in Sade, comes again and 
again as if it were the first time. This transgression of the very notion of time, by an illogical repetition, makes Sade's characters, who are always anxious for the glorious moment, permanently transgress, even within the logic of traditional use of language, the very condition of existence of Kantian subject (traditional time and space). Transgression in Sade, for Klossowski, is "the permanent recovering of the possible" (p. 23, my translation). There appears the radicality of Sade's attack against moral through moral itself.

Sade's characters, however, do not reach orgasm: they get ecstasy. The difference, says Klossowski, is that ecstasy is something that intensely involves body and thought at the same time, while orgasm works outside thought. In cinema, resuming what Badiou suggests, sexual exposition, particularly in its "repetitive visibility", may lead one to that objective inhumanity with no space or time for thoughts. Image of intimacy may bring up inhumanity. It does not lead to the utopia of Sade's "voluptuous insensibility" (Klossowski,p. 35), which could be something beyond human. It reminds one of something non-human.

If Badiou's suggestion makes sense, what could happen when images of genitalia are not repetitive, i.e., when they appear not in a series which is not supposed to include them? In other words, when they surprise spectators, when they are images suddenly juxtaposed to totally different images-even against previous images, in the moral sense? As I will argue below, this game of (surprising) images-againstimages reminds one of Benjamin's notion of history: a movement of reading done against the traditional flow of thoughts about the past, a stop to think. Quick shots of genitalia may correspond to sudden encounters with images of the inhuman, the non-cultural, which in turn, I argue, may lead thought to the enigma of being, or, at least, to the very problem of the passage from nature to culture-or, in Agamben's terms (2002), from zoé to bios, from nude life to culture, or politics.

To argue this way, I analyze here three sudden explicit images of genitalia, from three different films that do not have sex as their central subject: 
(1) Lígia's (Leona Cavalli's) vulva in Claudio Assis's Amarelo Manga (Brazil, 2002),

(2) Stoffer's (Jens Albinus's) erect penis in Lars von Trier's The Idiots (Denmark, 1998), and

(3) transsexual Dil's (Jaye Davidson's) penis in Neil Jordan's The Crying Game (USA, 1992).

All three images are explicit and surprising enough to provoke impact, both in diegetic and extra-diagetic spaces. In the diegetic space, they are surprising enough to change games in which characters are involved. In the three respective films, some characters get perplexed and change the attitude they have intended to keep in their games. In The Crying Game, the clear image of transsexuality determines the plot itself. In The Idiots, the clear image of erection makes it hard for the character to go on with his game of fake mental illness. And in Amarelo Manga, the game of seduction of the bar customer is dismissed by the clear image of vulva - the identity of the female character as "Brazilian woman" is problematized. Were those genitals kept invisible within clothes, the respective games could go on, perhaps indefinitely.

In the extra-diagetic space, the three shots in which those genitals appear are likely to turn viewers perplexed through a violent moral impact. In general, before seeing the films they would not expect such images. The three films were presented as belonging to "decent" categories. The Crying Game was advertised (by teasers, trailers, spots, newspaper stories etc) in the typical way most Hollywood films are presented: it was not supposed that spectators would expect to see any sexually explicit shot-much less a woman's penis. The idiots was brought to viewers as a Dogma 95 new release, with Lars von Trier's signature. The way it was advertised probably suggested some alternative, intellectual glance, from which one could expect anything. Even so, the first sexually explicit shot, the main character/actor's erect penis, looks obviously disconcerting for most viewers, even if they 
seldom make it clear in their "intellectual" attitudes. As to Amarelo Manga, it also can be said that anyone could expect many "strange" things from a film that was presented within a long series of Brazilian recent films that propose a sort of commitment with social misery: in the midst of poverty, at least from the point of view of film consumers' potential class prejudice, anything is possible. In the very beginning, Lígia is shown naked when waking up in the miserable room, close to the small dirty bar of which she is the only waiter. Yet, this is not enough for one to expect that, later on, her/Cavalli's vulva would fulfill the screen for seconds, as a solution for Lígia to shut up an inconvenient bar customer.

Obviously, all those impacts are rendered possible by moral. In an extra-moral sense, genitals would never be shocking. However, what I intend to suggest here is not such obviousness. I would like to compare the three images and investigate the very nature of their impacts- the way the three shots cleverly play with moral. I will not suppose that the three directors, in a kind of conspiracy, teamed up in order to shock audiences by cleverly playing with their cultural values-and succeeded. Rather, and this is my central hypothesis here, I want to read those shots, and their respective shocks, as ones that point out, through moral, the very way in which the passage from nature to culture may be seen as a game- probably a crying, perhaps tragic, one.

In fact, naked genitals may be seen as the extreme of nakedness itself. There is no beyond. At least in Western cultures, nakedness in general, even in direct contacts among human beings (without representational devices, as cameras or brushes), is a privileged sign of an erotic tension between nature and culture, or, as Bataille has already pointed out, between continuity (mutually dissolving bodies) and discontinuity (civilized individual bodies). Nakedness gives way to the huge, radical continuity of nature, of cycles, of life itself, with its great, challenging, lack of meaning. In modernity, a context in which biological life itself is the central subject of politics (see Foucault and Agamben 2004), the moment of being naked is ruled, and so is the game of seduction, which demands adequate time and space, adequate 
amounts of nature and culture. Now, when genitals themselves come out to plain visibility, in an "inadequate" moment, they stop the game and its ruled erotic tension. Suddenly, there is no longer discontinuity to break-no more adequate games. Nakedness in a "wrong" moment is a matter of shame, a minor rupture, that civility may cope with, applying its sanctions; explicit genitals, on the contrary, when inadequate or unexpected, are much more likely a matter of madness, sometimes monstrosity; they go out of the ruled space of games: it is the end of civilized eroticism, maybe of civilization itself-this seems to be the radicality of Bataille's eroticism in, for instance, L'histoire d'oeil.

As Susan Buck-Morss makes clear, when re-reading Benjamin's famous essay on the work of art, modern human bodies are armored by technology. Even glamoured nakedness is covered with technology (acquired from drugstores, fitness centers or nutritional and medical institutions) so as to make the body similar to the great (Greek) collective model of autothelic and autogenetic man-the same man who allegorizes modernity as a promise of happiness, the one who has ever been dreamed of, but who, in modernity, was believed as rendered possible by technology. Adequate nakedness, in sum, is not nakedness. Explicit genitals, on the contrary, are not included in modern dreams. The great, ideal modern body, as Buck-Morss points out, is strong, invulnerable, masculine-and castrated. It is anesthetized, it has no bodily responses for shocks or unpredictable, inconvenient happenings, it is above all of it-above erections.

Revisiting Benjamin's article as a theory of fascism, Buck-Morss reminds us that Lacan's conference on the mirror stage (another theory of fascism) was also presented in 1936, as Benjamin's text. She shows the terrifying way in which Benjamin could see fascism as a development of the narcissistic glance by the masses to themselves. Naked bodies as those filmed and edited by Leni Riefenstahl in Der Triumph des Willens and Olympia were obviously the greatest examples of fascist use of cinema in Benjamin's proposal. It is clear that the mechanism of fascist identification and anesthetization proposed by Benjamin/Buck-Morss could work fine with those perfect 
Riefenstahl non-explicitly-sexualized bodies. Any explicit genital would certainly interrupt the process.

Benjamin also indicates how adequately the machine (the movie camera) grasps the movement of masses to present it to masses themselves. The identification is possible only through the machine, only through the artificiality of all those fascist images-including the artificiality of that kind of nakedness shown in Riefenstahl films. Agamben (another reader of Benjamin) adds that man is the only animal that gets interested in images as such. Indeed, he argues, when dogs see a picture of a piece of meat, they can get excited, but their interest go away the very moment they notice that it was not really a piece of meat. Man, in contrast, is capable of cultivating values in images, even when they know that they are images, that they are not the "real thing". So, for Agamben (2004), it would be possible to define man as "the animal who goes to the movies".

Such a definition is possible only in a specific theoretical lineage of thinking about image. Also in Benjamin, the identification of masses with masses could only take place because of image itself. People seemed to fall in love with moving images. Agamben, then, associates the notion of moving images in Deleuze with Benjamin's conception of history as "dialectic image" - history is an image put against the flow of images, it is a suspension, a "stop to think". Image in cinema, then, with its dynamic tension, is not another form of history: it is history itself. "Historical experience is made by image, and images are themselves full of history" (Agamben, 2004, p. 97). At the same time, such a notion of image as history also echoes Deleuze's notion of image itself, which comes from Bergson, from whom images are everything that exist. We are images. Images are the "real thing". For Bergson, perception is part of mater, and mater is image. Images interact with one another, and each image is "a way through which, in all senses, all modifications that propagate in the immensity of universe pass by" (Bergson, p. 33).

Still, for Agamben the more deliberate are the cuts and repetitions that build a cinematic image, the less such image may be characterized as a mere medium, i.e., as something that disappears itself in what it 
gives us to see. The poetic image in film gives way for it itself to appear, it insists in appearing really as image, not as representation - as image of nothing. And that is the place for real, radical poetry. For Agamben, there are only two ways of showing this "no-image" in images. One of them is that radical, deliberate poetry made with cuts and repetition (as Agamben observes in Guy Debord). The other one, in contrast, with no poetical radicality at all, may be seen both in advertising and pornography.

On the pornographic image there is nothing to be seen beyond image. Image in main-stream film is part of the game of representation, in which spectators like to imagine (or image) things (or themselves) beyond the screen, like they do with a window or a mirror. In films like Debord's, that specially explore cuts and repetitions, there is nothing to see but image (and all the political consequences of the shallow cult of image in the "society of spectacle"). In pornography this "nothing to see" is banalized: what is shown is only what is shown (often for masturbation purpose).

Now, in the three films I analyze here, there is a mix of the categories commented above. In The Crying Game, main-stream flow of representation is interrupted by Dil's ambiguous genitalia. In The Idiots, image was already calling attention to itself, as such, given Von Trier's special procedures (such as frantic movements of that light digital camera), then Stoffer's penis is shown erect in the restroom, among women (and much later on, a scene of explicit sex alludes directly to pornography). In Amarelo Manga, representation is getting close to codes of $19^{\text {th }}$ Century naturalism in literature and painting, so also calling attention to itself as a game, but this game is broken by Lígia's vulva in the same sense. In the three cases, given the break of cinematic codes, we go from representation (problematized or not) to a problem with images of genitalia.

But what could be, really, this problem with images of genitalia? Considering the disconcerting, unpredictable aspect of those three shots I chose, and considering them as images, I would like to see them neither as medium that insists in not disappearing as such (although they are conflicting enough in the respective films), nor as mere representation 
(disappearing as image to give way to "real" genitalia). In this case, as another case of dialectic image, put against the flow of images that come before them, they are both a privileged place for seeing images as such, and genitalia as image (in the Bergsonian sense). Seeing them, one can see both cinematic images, strangely applied against others, and those parts of human bodies that goes (as images) against the ideal, imagined, non-sexualized collective body dreamed of by modernity.

Seeing those counter-images as genitalia themselves, with all the power to counter the flow of history in modernity, allows one to consider them, in their complex articulation with the films they are in, as a summary for the history of gender, as proposed by Linda Nicholson. It is really impressive that so many cultures still insist-even after biodeterminism, and after second-phase feminism and its biological foundationalism-in interpreting bodies and genitalia as still capable of defining gender characters and behaviors. Indeed, all gender problems, all gender prejudice and its consequences might be seen, in part, in the fact that those three insertions of genitals in films are problematic. Their explicit character, by which "there is no beyond", is a kind of evidence: genitals are turned into the truth about characters. Everything is interrupted for a moment: the plot of The Crying Game absolutely depends on the explicit revelation of Dil's genitalia; Stoffer's erection shows him the failure of his ability to playing games with the truth of characters' private lives; the whole genderized game of power that goes along with class struggle is challenged by Lígia's vulva.

So, the Deleuzean retard between any thing-as-image and itself, specially when its very moral strangeness is considered, may indicate the way in which genitalia, as image, turn into enigma, in the very passage from nature to culture. The contrast between such simple and clear images and all those complex games corresponds to the nature of the impact of the shots considered here. The three shots give back to those clear images of genitalia the property they have always had: their character of central pieces in the game of such passage. 


\section{Note}

1. Oil on canvas, $1866,181 / 8 \times 215 / 8$ in. ( $46 \times 55 \mathrm{~cm}$ ), Musee d'Orsay, Paris. Retrieved April 10, 2006, from http://artchive.com/artchive/C/courbet/ origin.jpg.html.

\section{References}

Agamben, Giorgio. Homo sacer. Belo Horizonte: UFMG, 2002.

Badiou, Alain. "La captura cinematográfica de los sexos". In: Badiou, Alain. Imágenes y palabras: escritos sobre cine y teatro. Translated by Maria Del Carmen Rodríguez. Buenos Aires: Manantial, 2005. 87-100

Barthes, Roland. A câmera clara. Rio de Janeiro: Nova Fronteira, 1984.

Bataille, Georges. O erotismo. Porto Alegre: L\&PM, 1978. . A história do olho. São Paulo: Cosac \& Naify, 2003.

Benjamin, Walter. "A obra de arte na era de sua reprodutibilidade técnica". In: Magia e técnica, arte e política. São Paulo: Brasiliense, 1985. 165-196.

Bergson, Henri. Matéria e memória. São Paulo: Martins Fontes, 2005.

Buck-Morss, Susan. "Estética e anestética: o ensaio sobre a obra de arte de Walter Benjamin revisitado". Travessia. 33 (1996): 11-41.

Deleuze, Gilles. Cinema: a imagem-movimento. São Paulo: Brasiliense, 1985. Imagem-tempo: cinema 2. São Paulo: Brasiliense, 1990.

Dyer, Richard (ed.). Gays and Film. New York: New York Zoetrope, 1984.

Foucault, Michel. História da sexualidade, v. 1: vontade de saber. São Paulo: Graal, 2003.

Nicholson, Linda. "Interpreting Gender". In: The Play of Reason: from the Modern to the Postmodern. Ithaca: Cornel University Press, 1999. 53-76. 
Nietzsche, Friedrich. "Sobre verdade e mentira no sentido extra-moral". In: Nietzsche (Coleção Os pensadores). São Paulo: Nova Cultural, 1996. 51-60.

Nietzsche, Friedrich. Genealogia da moral. São Paulo: Companhia das Letras, 2003.

Rancière, Jacques. "D'une image à l'autre: Deleuze et les âges du cinéma". In: La fable cinematographique. Paris: Seuil, 2001. 145-163.

Sloterdijk, Peter. No mesmo barco: ensaio sobre a hiperpolítica. São Paulo: Estação Liberdade, 1999.

Williams, Linda. Hard Core: Power, Pleasure, and the "Frenzy of the Visible". Berkeley: University of California Press, 1999. 